\title{
Titkos eszközök alkalmazása a rendőri korrupciós büncselekmények nyomozásában
}

\author{
Use of secret tools in the investigation of police corruption offenses
}

\begin{abstract}
Absztrakt
A rendészeti korrupciós büncselekmények fokozott társadalmi veszélyességüek, hiszen az állampolgárok rendészeti szervekbe vetett bizalmát alááshatják, biztonsági deficitet okozhatnak. Ezeknek a büncselekményeknek a megelőzése, felderítése éppen ezért kiemelt feladat a hatóságok számára. Ugyanakkor a rendészeti korrupciós büncselekmények felderítése, nyomozása - több tényező miatt - rendkívül nehéz, és a nyílt eszközök sokszor nem is elegendők az eredményes bünüldözéshez. A hatékony bünfelderítés érdekében nélkülözhetetlen tehát a leplezett eszközök alkalmazása, a konspirált adatszerzés. Jelen tanulmányban a jogszabály által meghatározott leplezett eszközöket vizsgálja a szerző abból a szempontból, hogy milyen módon alkalmazhatók a rendőri korrupciós büncselekmények miatt indult büntetőeljárásokban. Elemzi továbbá a hatályos Be. általi szabályrendszert abból a perspektívából is, hogy a gyakorlati tapasztalatok alapján mennyire fedi le a felderítés teljes igényrendszerét.
\end{abstract}

Kulcsszavak: rendészet, korrupció, integritás, titkos eszközök

\begin{abstract}
Corruption crime cases in law enforcement have extended risks for the society, as they may undermine confidence of the citizens in law enforcement organs, causing safety deficits. Prevention and elucidation of these crimes are equally important tasks for the authorities. Simultaneously, prevention and elucidation of corruption crimes in law enforcement is - due to several factors - very difficult, and open methods are frequently not enough for a successful prosecution. For an effective elucidation are use of secret tools and gathering data in
\end{abstract}


conspiracy indispensable. In the present paper the author examines certain legally specified secret tools from the aspect how they can be used in criminal procedure of police corruption crimes. Further he analyses the effective regulation system in criminal procedure, also from the perspective how they can cover the total demand system of elucidation, upon practical experiences.

Keywords: law enforcement, corruption, integrity, secret devices

\section{Bevezetés}

Már évtizedek óta fokozott társadalmi veszélyességünek tekintik a korrupciós büncselekményeket, mivel alááshatják a hatóságokba vetett bizalmat, megzavarhatják az ügyek elfogulatlan, objektív intézését, és ezzel az állampolgárokban a bizalmatlanság érzését keltik. A társadalmi veszélyességet nem elsősorban gyakoriságuk határozza meg, hanem az a tény, hogy az elkövetök egy része hivatalos személy, akik a büncselekmény elkövetésekor éppen beosztásukkal élnek vissza (Rudas \& Hoffman, 1973, 75.). Az elmúlt évek fejleményei (például a pénzügyi és gazdasági válság, a klímaváltozás hatásai, a terrorizmus és az illegális bevándorlás elleni fellépés) megerősítették, hogy a közjó absztrakt normarendszerének érvényesítése érdekében az államnak kell értékteremtő és értékvédő szerepet vállalnia a politikai, gazdasági és társadalmi szférákban. Ezt fejezi ki a jó állam fogalma, amely a közjó és a közszolgálati etika normáira támaszkodva szorosan összekapcsolódik a jó kormányzás és a jó közigazgatás fogalmával (Kaiser, 2017, 5.). A jó állam, mint komplex jelenség egyik fontos feladata a közbiztonságot és közrendet sértő vagy veszélyeztető cselekmények felderítési eredményességének fejlesztése. A hatékony bünüldözés mögött pedig elméleti alapokon nyugvó, gyakorlatban hasznosítható eszközök és módszerek rejlenek, amelyek együttesen egy sajátos, számos tudományterületet magában foglaló rendszert alkotnak, ami nem más, mint a kriminalisztika (Hautzinger, 2019, 84.). A kriminalisztika tudományának tárgya a nyomozás, a felderítés, melybe tágabb értelemben beletartozik a titokban történő információgyüjtés, illetve a titkos adatgyüjtés során történő megismerés is. Ennek legitim célja annak eldöntése, hogy szükséges-e a nyomozás formális megkezdése, illetve, hogy várható-e elegendő információ a vádemelés megalapozására (Bócz, 2004, 970976.). A bünügyi szolgálati ismeretek, azaz a bünügyi titkos információgyüjtés és a hozzá kapcsolódó kérdések kriminalisztikával való kapcsolatát az alapozza meg, hogy a titkos információgyüjtés során tulajdonképpen az egyes krimináltechnikai, krimináltaktikai és kriminálmetodikai tételek speciális alkalmazása 
történik (Balláné, 2014, 11.). A kriminalisztika késői érdeklődése után gyorsan előtérbe került ez a terület és a jövőbeli tendenciák között is az prognosztizálható, hogy a titkos erők-eszközök-módszerek alkalmazási köre szélesedni fog, új metódusok bevezetése, alkalmazása várható (Fenyvesi, 2014, 242.). Az elmúlt évtizedekben a világban bekövetkezett változások (globalizáció, technikai fejlödés stb.) a bünözés átalakulásához vezettek (például a szervezettség növekedése, az informatikai eszközök fokozottabb használata). Ennek következtében a hagyományos, nyílt nyomozási eszközök napjainkban már nem elegendők az eredményes bünüldözéshez (Fenyvesi, 2014, 219.). A titkos eszközök használata a speciális nyomozati eszközök táborába sorolható, egyes büncselekmények felderítése alkalmával a használatuk legtöbbször nélkülözhetetlen, mivel az elkövetők tevékenységének, munkamenetének megismerése, felderítése a titkos eszközök nélkül legtöbb esetben lehetetlen (Nyitrai, 2014, 32.). Ezek rendszerint olyan deliktumokhoz kapcsolódtak, melyek a tárgyi környezetben észlelhető nyomot nem hagynak, a cselekmény büntetendő jellegét nehéz felismerni, a véghezvitelt erőteljes konspiráció övezte, az elkövetési magatartás elökészületi stádiumban marad, vagy a törvényi tényállás előkészületi jellegü cselekményt rendel büntetni befejezett büncselekményként. Az is tipikus, hogy a bünténynek nincs természetes személy sértettje, vagy - ha van - annak nem füződik érdeke a büncselekmény felderítéséhez, illetve kényszer vagy fenyegetés hatása alatt nem tesz feljelentést (Bócz, 2004, 970-976.). Ilyen jellemzőkkel rendelkeznek a vesztegetési ügyek is. A korrupciós büncselekmények nyomozását több tényező együttese teszi rendkívül nehéz feladattá. Ki kell emelni azt, hogy a tanúbizonyítás nehéz vagy kizárt, mert a deliktumról csak szük kör, sokszor csak az előnyt adó és annak elfogadója tud, akiknek az érdekközössége is azonos, és természetes személy sértettről sem gyakran beszélhetünk. Figyelembe kell azt is venni, hogy a tárgyi bizonyítási eszközök feltárása is nehézségeket jelent, föleg, ha az elkövetés tárgya nem anyagi természetủ előny, illetve amikor a büncselekmény csak az előny kérésével, ígéretével válik befejezetté. Mindezek alapján egyértelmü, hogy a hagyományos nyomozati eszközök és módszerek ezeknek a büncselekményeknek a felderítésében, bizonyításában jellemzően kevésnek bizonyulnak. A hatékony bünfelderítés érdekében elötérbe kerülnek a leplezett eszközök, a konspirált adatszerzés. A titkos eszközökkel beszerzett adatok bizonyítékként való felhasználhatóságának biztosítására különös figyelmet kell fordítani. Szem elött kell tartani, hogy „a bünfelderités eredményességének igazi értékmérője ... a birósági tárgyalás, a hol a bizonyitékoknak ki kell állniuk a védelem próbáját, biztositani kell a fegyverek egyenlöségét és a jogorvoslati jogát" (Finszter, 2000, 110.). Jelen tanulmányomban a rendelkezésre álló titkos, illetve leplezett eszközöket vizsgálom meg abból a szempontból, hogy milyen módon alkalmazhatók 
a rendőri korrupciós büncselekmények miatt indult büntetőeljárásokban. Az eszközöket két részre bontva elemzem: az 1994. évi XXXIV. Rendőrségi törvényben (továbbiakban: Rtv.) foglaltak szerint a büntetőeljárás megindítását megelőzően használható titkos eszközök, illetve a büntetőeljárásról szóló 2017. évi XC. törvény (a továbbiakban: Be.) által szabályozottan a büntetőeljárásban alkalmazható leplezett eszközök.

\section{A büntetőeljárás megindítását megelőzően használt titkos eszközök}

A titkos felderítési lehetőségek alkalmazásának nagy előnye, hogy nemcsak a büntetőeljárás alatt, hanem már a büntetőeljárás előtti időszakban, az adatgyüjtésben is segítséget jelent (Fenyvesi, 2014, 220.). A büntetőeljárást megelőzően használt eszközök két csoportját a bírói engedély szükségessége különbözteti meg ${ }^{1}$.

\section{Bírói engedélyhez nem kötött eszközök}

A bírói engedélyhez nem kötött eszközök célja a büncselekmények megelőzése, megakadályozása, a titkos információgyüjtés erőinek, eszközeinek védelme, biztosítása. A bírói engedély nélkül alkalmazható titkos eszközök első csoportjába az információk megszerzése érdekében a rendőrséggel titkosan együttmüködő személy tartozik ${ }^{2}$. Az együttmüködő több szintủ is lehet annak függvényében, hogy egyszeri, illetve eseti jelleggel vagy rendszeresen szolgáltat információt. A felderítő szervnek biztosítani kell ezeknek a személyeknek a védelmét, azaz személyes adatai, a rá vonatkozó információk, a vele való együttmüködés ténye nem derülhet ki. Az önálló információszolgáltatáson túl, a titkosan együttmüködő célirányosan foglalkoztatható, részére feladat határozható meg, de nagy mennyiségú információk feldolgozásában is segíthet, illetve technikai rögzítő eszközök konspirált módon történő szerelésénél (telepítéseknél) fedést biztosíthat (például az együttmüködő tevékenységéből adódó lehetőségek fedősztoriként történő felhasználása révén).

Bírói engedély nélkül lehetőség van fedett nyomozó, illetve kilétét leplező rendőr igénybevételére ${ }^{3}$, de csak információ gyűjtésére, ellenőrzésére. A rendőri

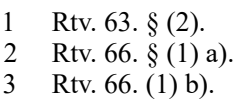


korrupcióval összefüggésben a fedett nyomozó jellemzően közvetlenül a célszemélyi körbe vagy azok közelébe kerül bevezetésre, föként puhatolásra alkalmazható. Igyekszik bizalmi viszonyt kialakítani, szükség szerint dokumentál, gyanús ügyletek látszatát kelti, és ennek keretében gyüjt információt a célszemélyi kör reakcióiról. A fedett nyomozó szerepe valójában a büntetőeljárásban, akár már az előkészítő eljárás során kiteljesedhet. Lehetőség van arra is, hogy a rendőrség személyt, lakást, egyéb helyiséget, bekerített helyet, nyilvános vagy a közönség részére nyitva álló helyet, illetve járművet titokban megfigyeljen, a történtekről információt gyüjtsön, valamint az észlelteket technikai eszközzel rögzítse, azaz klasszikus titkos megfigyelést hajtson végre ${ }^{4}$. Ezt a tevékenységet akár élő erővel, akár eszközzel is lehet végezni. A korrupciós cselekmények esetében a gyakorlatban ezt az eszközt olyan közterületen alkalmazzák, ahol az elkövetés megvalósulhat vagy bármilyen más releváns információ birtokába lehet jutni (például pénzváltó közelében). Eredményesen használható továbbá a célszemélyek kapcsolatainak felderítésére, rejtekhelyek megállapítására is. Bár lehetőség van arra, hogy valamely személyt - ha életének, testi épségének megóvása érdekében szükséges - rendőrrel helyettesítsenek ${ }^{5}$, a korrupciós büncselekmények felderítése esetében ennek az eszköznek az alkalmazása nem jellemzö, csak elvétve fordulhat elö. Az elektronikus hírközlési eszközön vagy információs rendszeren folytatott kommunikáció tényének a megállapításához, az elektronikus hírközlési eszköz vagy információs rendszer azonosításához, illetve hollétének megállapításához szükséges adatok megszerzésének a lehetősége ${ }^{6}$ már a vizsgált büncselekmények vonatkozásában is hatékony eszköznek számít. Alapvetően a híváslista adatok beszerzése, a telefon azonosító adatainak vagy helyzetének megállapítása a gyakorlatban bizonyítja két személy közt fennálló kapcsolatot. Az ügy jellegétől függően akár bünös kapcsolatra is utalhatnak az innen kinyert adatok. Erre példa lehet az, ha szolgálatban annak ellenére tartja magánál a rendőr saját mobiltelefonját, hogy bizonyos szolgálati helyeken ez - külön engedély hiányában - tilalmazott ${ }^{7}$, és - a híváslista alapján -

4 Rtv. 66. $\S(1) \mathrm{c})$.

5 Rtv. 66. $\S(1) \mathrm{d})$.

6 Rtv. 66. $\S(1)$ e).

7 A rendőri korrupciós cselekmények megelőzésével és visszaszorításával kapcsolatos feladatokról szóló 20/2013. (V. 17.) ORFK utasítás 30/B. pontjában foglaltak szerint: „A közterületen, a közúti, vasúti, légi, vizi határátkelöhelyen, a fogdában, az örzött szálláson, az őrzött létesitményben, illetve az elóállító egységben ellátott határrendészeti, közlekedésrendészeti, közrendvédelmi, illetve objektumvédelmi szolgálat hivatásos állományú tagja a szolgálatban magántulajdonú mobiltelefont nem tarthat magánál, kivéve ha azt a szolgálati elöljáró - a belügyminiszter irányítása alatt álló rendvédelmi feladatokat ellátó szervek hivatásos állományú tagjai által szolgálatban birtokban tartható vagyontárgyak, magáncélú telekommunikációs eszközök, készpénz, készpénzt helyettesitö eszközök korlátozásának szabályairól szóló 21/2015. (VI. 15.) BM rendelet 4. § (2)-(3) bekezdéseiben foglaltak alapján, írásban vagy az irásba foglalás akadályoztatása esetén szóban - engedélyezte." 
telefonál is vele, mégpedig bünös kapcsolatával folytat beszélgetést. Lényeges információ lehet az is, ha arra merülnek fel adatok, hogy egy rendör csak megcsörget egy számot, és mindig csak azután hívja fel őt egy adott személy. Amennyiben már megvan a bünös kapcsolat, akkor annak addig ismeretlen pozíciójának és kilétének megállapítására használható a készülék hollétének megállapítása. Meg kell említeni, hogy a hivatkozott norma ugyan a mobiltelefon birtoklására vonatkozóan tartalmaz korlátozó rendelkezést, a majdnem azonos funkciókra alkalmas okosórákra azonban nem. Az eszközök közül vannak, amelyek bluetooth segítségével a telefontól 10 méterre is használhatók, illetve olyanok is, amelyek saját SIM kártyával müködnek. Érdemes elgondolkodni azon, hogy a technikai fejlödés követése mennyire fontos az élet valamennyi területén, így a korrupció elleni küzdelemben is. Szükség lenne például az okosórákra is kiterjeszteni a mobiltelefonokra vonatkozó korlátozó rendelkezést. Ennek hiányában pedig kiemelt figyelmet kell fordítani azokra a személyekre, akik szolgálatban ilyen eszközöket viselnek. A technika fejlődésével egyre nagyobb szerepet kaphat az a rendelkezés, amely szerint a rendőrség a titkosan együttmüködő személy által rendelkezésre bocsátott információkat - hozzájárulásával - müszeres ellenőrzéssel vizsgálhatja ${ }^{8}$. A Nemzeti Védelmi Szolgálatnál (a továbbiakban: NVSZ) három részből álló szakértői tevékenységet végeznek. A poligráfos vizsgálat mellett a réteges hangelemzés és videókép analitika alkalmazására is sor kerül, vagyis a vizsgálatok képanyagainak pszichológus általi elemzésével egy olyan, három részből álló szakértői tevékenység került kialakításra, amely nemcsak Magyarországon, hanem Európában is egyedülállónak számít. A réteges hangelemzés elvégzésére elegendő a hangfelvétel. A videókép-analitika pedig a felvett képanyagok pszichológus általi elemzése. Az együttmüködő személyes közremüködését egyik módszer sem igényli, tudtán kívül zajlik, mégis szavahihetőségére vonatkozó hasznos információkra lehet belöle következtetni. A leggyakrabban alkalmazott eszköz a poligráf. Használatát, annak minden előnyével és hátrányával együtt, alaposan mérlegelve át kell gondolni, hiszen a kapcsolattartás során a bizalom elvesztésével is járhat. Amennyiben azonban sérülésmentesen kivitelezhetö, akkor rendkívül hasznos eszköz lehet. Elöfordulhat ugyanis, hogy az együttmüködő nem teljes mértékben mond igazat vagy alapvetően a fontos információk tekintetében igazat mond, csak pár - kevésbé releváns dologban torzítanak az általa elmondottak. Egy müszeres ellenőrzéssel ezeket a kis mértékben elferdített adatokat ki lehet igazítani. Amennyiben pedig a titkosan együttmüködő személy folyamatosan valós információkat közöl, akkor a müszeres ellenőrzés segít abban, hogy a jövőben se próbálja a hatóságot megtéveszteni.

8 Rtv. 66. § (1a). 
Valós, felhasználható információkat közlő együttmüködő esetén a poligráf alkalmazása szakmailag nem elfogadott a bizalomvesztés veszélye miatt. A hazugságellenőrző vagy más néven őszinteségellenőrző (Hautzinger, 2004, 43-51.) technikák közül a poligráf dominanciája úgy tünik még sokáig megmarad, annak ellenére, hogy már számos más módszer is rendelkezésre áll. A hatályos Be. jogilag is megteremtette a lehetőséget más müszerek alkalmazása előtt. ${ }^{9}$ A poligráf nemcsak Magyarországon, hanem világszerte is a legismertebb müszer, amely emellett az egyetlen megfelelően validált müszeres vallomásellenőrző módszer (Budaházi, 2018, 42.). A poligráfon kívül alkalmazzák továbbá a komputeres grafometriás vizsgálatot és a rétegzett hangelemzőt is, valamint a hőkamerát. Határainkon kívül ismert még a funkcionális mágneses rezonancia vizsgálat (fMRI), a monoszkenner, a tulajdonságszürési technológia (Future Attribute Screening Technologies - FAST), a csendes beszélö (Silent Talker), a pszichológiai stresszértékelő (PSE) és a szemhőmérő is (Budaházi, 2013, 17-18.). Az agyi ujjnyomat teszt segítségével nem nyerhetünk információt a bünelkövetésre, ártatlanságra, becsületességre, félrevezetésre, hazugságra, illetve bizonyos cselekedet elkövetésére vagy el nem követésére. Azonban adatot nyerhetünk bizonyos információk meglétéről (az információ a vizsgált személy rendelkezésére áll) vagy hiányáról, esetleg arról, hogy ilyen információ meglétére vagy hiányára a teszt alapján nem lehet következtetést levonni. Ki kell emelni, hogy az eddigi adatok alapján, téves pozitív eredmény (azaz amikor egy ártatlan személy a teszten pozitív eredményt mutat) viszonylag ritkán; téves negatív teszteredmény viszont gyakrabban fordul elő. Mivel a büntetőjogi rendszer erősen arra az elvre épül, hogy egy ártatlan személy elítélése (téves pozitív hiba) rosszabb, mint egy bünös személy felmentése, így a módszer forenzikus eszközként jelentős potenciállal rendelkezik (Czobor et al, 2018, 65-66.).

Ki kell térni a megbízhatósági vizsgálat speciális jogintézményére is ${ }^{\mathbf{1 0}}$, melynek célja a valóságban is előforduló élethelyzetek mesterséges kialakításával annak ellenőrzése, hogy az érintett eleget tesz-e a jogszabályban elöírt hivatali kötelezettségének, a jogszerü, befolyásmentes feladatellátás követelményének. Az NVSZ kizárólag ügyészi engedély birtokában, részletesen kidolgozott végrehajtási terv alapján hajthat végre megbízhatósági vizsgálatot, amelynek során a védett állomány tagját foglalkoztató szerv hivatali helyiségében, gépjármüvében és a megbízhatósági vizsgálat helyszínén történteket, illetve a mesterséges élethelyzetben résztvevő, valamint a megbízhatósági vizsgálat alá vont személy tevékenységét és előadását titokban technikai eszközzel megfigyelheti

9 Be. $212 . \S(1)$.

10 Rtv. 7/A-7/D. §, Rtv. 66. § (2). 
és rögzítheti, illetve az ehhez szükséges technikai eszközt a felsorolt helyeken elhelyezheti. A belső bủnmegelőzési és bünfelderítési szerv a megbízhatósági vizsgálatok során gyakran alkalmaz olyan speciális konspirált kép- és hangrögzítő eszközöket, melyek ruházaton vagy annak kiegészítőin, egyéb használati eszközökbe kerülnek elrejtésre. Ezekkel az eszközökkel gyakran gépkocsiban, irodában, magánlakásnak minősülő egyéb helyen hajtanak végre dokumentálást. Emellett arra is van példa, hogy egy előre beállított helyszínen telepítenek hagyományos tereptárgyaknak látszó, valóságban preparált eszközöket. Csak és kizárólag az ügyész által engedélyezett mesterséges élethelyzetben zajló eseményeket lehet rögzíteni, ez a gyakorlatban például a lezajlott beszélgetést, a beállított mesterséges helyszínt jelenti. Nem jár tehát olyan alapvető jogok korlátozásával, sérelmével, amilyenről egy büntetőeljárás során alkalmazott, bírói engedélyhez kötött eszköz esetén beszélhetünk, ahol nem mesterséges élethelyzetről beszélünk, melynek alkalmazásához épp a sérelem okán szükséges a bírói engedély, mint végső eszköz. Az ügyész által engedélyezett végrehajtási tervnek tartalmaznia kell, hogy a vizsgálatot végző szerv pontosan hol és milyen eszközök használatát tervezi. Az ügyészi felügyelet mellett folyó eljárás során igénybe vehetők a titkos információgyüjtés bírói engedélyhez nem kötött eszközei is, melyek a bizonyítékok rögzítését, beszerzését szolgálják.

A titkos információgyüjtés erőinek, eszközeinek védelme érdekében alkalmazható titkos eszközök közül a rendőri korrupciós cselekmények felderítése vonatkozásában négyet ki kell emelni.

1.) Az Rtv. 64. § b) pontja külön nevesíti a megbízhatósági vizsgálatot, amely a korrupció elleni fellépés sajátos eszköze. A több országban alkalmazott módszert Magyarországon 2011-ben vezették be, melynek preventív hatása is kimagasló. Ez a szabály tulajdonképpen egy speciális titkos információgyűjtésről rendelkezik. A rendőri korrupciós cselekményekkel összefüggésben azonban külön rendelkezés került beiktatásra, mely szerint a rendőrség belső bünmegelőzési és bünfelderítési feladatokat ellátó szerve a megbízhatósági vizsgálat során is folytathat titkos információgyüjtést, ha ez az ügyészség által jóváhagyott elrendelő határozatban szerepel. A specialitása több részletszabályban is kereshető, melyek a következők: előzetes ügyészi engedély szükséges, rövid idő áll rendelkezésre $(15+15$ nap), teszt jellegü, bírói engedélyhez kötött eszközök alkalmazása történik. Emellett pedig a vizsgálattal érintett személyt az eljárás végén kötelezö értesíteni. Amennyiben büncselekmény kerül megállapításra az érintett személlyel szemben, és büntetőeljárás megindítására kerül sor, akkor a titkos információgyüjtést is megismerheti. A gyakorlatban éppen emiatt 
ez nem kedvelt módszer. A megbízhatósági vizsgálat egy komplex kidolgozott végrehajtási terv alapján kerül végrehajtásra, egy előre tervezett és kialakított élethelyzetben. A szigorú ügyészi kontroll alatt a vizsgálatot végző szerv igyekszik a kialakított élethelyzet során felmerülő valamenynyi várható elkövetési módot behatárolni, és a tárgyalótiszt által követendő magatartásformát, az általa elkövethető büncselekmények minősítését pontosan meghatározni, azokat a végrehajtási tervben rögzíteni.

2.) Az Rtv. 64. § g) pontban írt szabályozás lehetőséget ad arra, hogy titkos információgyüjtést lehessen végezni bírói engedélyhez kötött leplezett eszközök alkalmazása során igénybe vett technikai eszköz vagy adat elhelyezése, valamint eltávolítása érdekében. Ez a felhatalmazás a rendőri korrupciós büncselekmények felderítése során komoly lehetőséget ad a bünfelderítő hatóság kezébe. A gyakorlatban többször előfordul, hogy a büntetőeljárásban az ügyész arra kéri fel az NVSZ munkatársait, hogy nyomkövetö-, kép és/vagy hangrögzítő eszközt telepítsenek az eljárásban érintett személy lakásába, irodájába, gépjármüvébe. Ebben az esetben az ügyész adja meg az engedélyt az eszközre vagy kéri meg a bírótól, és az NVSZ állományának tagjai hajtják végre annak kivitelezését. A végrehajtás sokszor rendkívül bonyolult, hiszen előfordulhat, hogy személlyel, céggel történő együttmüködésre van szükség, vagy éppen csak fedést kell biztosítani. A gyakorlatban szükség lehet az eszköz alkalmankénti felügyeletére, illetve eltávolítására. A hatályos szabályok szerint ezekre az esetekre is elrendelhető titkos információgyüjtés.

3.) Az Rtv. 64. § h) pontjában foglaltak szerint a fedett nyomozó, illetve a valódi céljának leplezésével működő szervezet védelme érdekében a rendőrség titkos információgyüjtést folytathat. Az Rtv. 64. § g) pontjában foglalt szabályhoz hasonlóan az ügyész engedélyezi a fedett nyomozó alkalmazását, a védelmére pedig el lehet rendelni titkos információgyüjtést. Ebben az esetben - a fedett nyomozó védelme érdekében - lehetőség van adatainak figyelőztetésére, valamint élő erővel történő figyelés szervezésére. Ez utóbbira szükség lehet - többek között abban az esetben -, ha találkozik a célszemélyi körrel.

4.) Az Rtv. 64.§ i) pontja arról rendelkezik, hogy a rendőrséggel titkosan együttműködő személy védelme, bevonása és ellenőrzése érdekében a rendőrség titkos információgyüjtést folytathat. Az együttmüködő védelme hasonló, mint a fedett nyomozó esetében. Az együttmüködőt is szükséges ellenőrizni, hogy dekonspirálódott-e a környezetében, vagy ott, ahol foglalkoztatjuk. Figyelemmel kell lenni arra is, hogy kellő konspirációval jár-e el, hiteles, megbízható-e a személye. 


\section{Bírói engedélyhez kötött eszközök}

A bírói engedélyhez kötött titkos információgyüjtés már nagyobb mértékü beavatkozást jelent a magánszférába, amelynek keretében a hatóság a nyomozás elrendeléséig titkos kutatást végezhet, helyet titkosan megfigyelhet, küldeményt titokban megismerhet, lehallgatást végezhet, információs rendszert titkosan megfigyelhet ${ }^{11}$. A titkos kutatást a korrupciós büncselekmények felderítésénél alapvetően számlák, nyugták, bizonylatok, fekete könyvelés, hamis vagy hamisított magán-, illetve közokiratok megismerésére alkalmazzák. A hely titkos megfigyelése olyan gépjármüvek, épületek kontrollálását jelentheti, ahol a bizonyítás szempontjából releváns adatok keletkezhetnek. Nagy hatásfokkal alkalmazható a szolgálati helyiségekben, gépjárművekben történtek technikai eszközzel való megfigyelése. A felvételeken láthatóvá válhat, hogy az állomány által a térfigyelő kamerák tekintetében holt térnek minősülő helyeken fogadják el és rejtik el a vesztegetés tárgyát jelentő készpénzt. A titkos kutatáshoz hasonló, bár specifikusabb eszköz a küldemény titokban történő megismerése, melynek alkalmazásával ugyanolyan adatok (például bizonylatok, számlák, okiratok tartalma) birtokába kerülhetünk. A korrupciós büncselekmények felderítésében eredményt hozhat a lehallgatás, az információs rendszer titkosan történő megfigyelése, bár hatásfokuk jóval kisebb az inkriminált helyiségek, helyszínek rejtett megfigyelésével gyüjtött információkhoz képest. A klasszikus értelemben végrehajtott lehallgatás mellett ide tartozik a telefonon, illetve egyéb számítástechnikai eszközön tárolt adatok titokban történő megismerése is. A gyakorlatban egy adott müveletben ezeket a lehetőségeket gyakran kombinálják. Erre példa, ha egy titkos kutatás végrehajtása közben hozzáférnek egy számítógéphez, amelyről releváns adatokat ismernek meg, mentenek le. A rendőri korrupciós büncselekmények vonatkozásában egy lényeges, speciális rendelkezést tartalmaz a törvény. Ennek értelmében a védett állománynyal összefüggö, jogszabályban meghatározott büncselekmények megelőzése céljából a rendőrség belső bünmegelőzési és bünfelderítési feladatokat ellátó szerve akkor is folytathat bírói engedélyhez kötött titkos információgyüjtést, ha megalapozottan feltehetö, hogy attól a védett szerv befolyásmentes müködésének megzavarásával, illetve tagjai vagy valamely állománycsoportja szolgálatellátásának befolyásolásával kapcsolatban olyan információ megszerzése várható, amely a későbbiekben megalapozza a büntetőeljárásról szóló törvény szerinti leplezett eszköz alkalmazását is. Ez a szabályozás is bizonyítja, hogy a törvényalkotó kiemelten kezeli - többek között - a rendőri korrupció elleni

11 Rtv. 70-72. §. 
hatékony és eredményes fellépést, a rendőrség befolyásmentes müködésének biztosítását. Tekintettel a titkos információgyüjtés céljára az Rtv. alapján alkalmazott eszközök nem alkalmasak a bizonyítékok beszerzésére, felhasználásukra csak kivételes esetben kerülhet sor. A bizonyítékok beszerzésének a jelenlegi szabályozás szerint a büntetőeljárásban kell megtörténnie. Éppen ezért a gyakorlatban a titkos információgyüjtések szerepe visszaesett.

\section{A büntetőeljárás megindítását követően használt leplezett eszközök}

A leplezett eszközök alkalmazására - jellemzően - a nyomozás két szakaszában: a felderítés és a vizsgálat során kerül sor (URL1). A hatályos Be. bevezette az előkészítő eljárást, amit éppen a bünüldözési célú titkos információgyüjtés szabályainak büntetőeljárásba integrálása tett szükségessé. Ezzel lehetővé vált, hogy egyszerü gyanú szintjét el nem érö információk alapján is indítható legyen büntetőeljárás. Abban az esetben van erre lehetőség, amennyiben a rendelkezésre álló adatok a büncselekmény gyanújának megállapítására nem elegendők, és megalapozottan feltehető, hogy az előkészítő eljárás lefolytatása alapján el lehet dönteni, a büncselekmény gyanúja fennáll-e (Mészáros, 2018, 177-178.). Ez azt jelenti, hogy az egyszerü gyanú szintjét el nem érő adatok alapján előkészítő eljárás indítható, melynek során több leplezett eszköz alkalmazható. ${ }^{12}$ Az új rendelkezéssel kapcsolatban a gyakorlati szakemberek részéről felmerültek különböző aggályok is. Az egyik szerint ,'igy bármilyen forrásból származó, szakmai tevékenysége során a hatóságok tudomására jutott információ elégséges lehet a gyanú gyanújának fennállásához" (URL1). A törvényjavaslat miniszteri indokolásában azonban szerepel, hogy az előkészítő eljárás sorsát felül fogják vizsgálni és az eljövendő időszak ellenérveinek meggyőző ereje vagy más jogállami kontroll eredménye döntheti el meghagyását vagy a jövőbeni elhagyásának a lehetőségét. Az előkészítő eljárás bevezetésével a bünüldöző hatóságok egy új lehetőséghez jutottak, hiszen ezzel az eredményes bünüldözésüket a jogalkotó megkönnyítette. Ez a megállapítás természetesen a korrupciós büncselekmények vonatkozásában is megállja a helyét. Mindezek ellenére a bünüldözés sikere nem állhat mindenek felett. Még az egyszerü gyanú szintjét sem elérő információ alapján megindított büntetőeljárás, és

12 A Be. 341. §-ában foglaltak szerint a következő leplezett eszközök alkalmazhatók: titkosan együttmüködő személy; információgyűjtés és információellenőrzés az eljárás valódi céljának titokban tartásával; rejtett figyelés; fizetési müveletek megfigyelése; álvásárlás; fedett nyomozó; valamennyi bírói engedélyhez kötött eszköz. 
ennek során alkalmazott leplezett eszközök felvethetnek olyan jogi kérdéseket, anomáliákat, melyekre mindenképp adekvát választ kell adni a jogalkotásban és a jogalkalmazásban egyaránt. Azaz meg kell teremteni az egyensúlyt a bünüldözési érdek és a magánszféra tiszteletben tartása között.

A Be. különbséget tesz az előkészítő eljárás és a nyomozás során alkalmazható eszközök köre között. Az előkészítő eljárás során a törvényben nevesített leplezett eszközök közül kizárólag a titkosan együttmüködő személy igénybevétele, titkos információgyüjtés, rejtett figyelés, fizetési müveletek megfigyelése, fedett nyomozó, büncselekménnyel feltehetően összefüggésbe hozható dolog vagy szolgáltatás igénybevételére álvásárlás, illetve bírói engedélyhez kötött leplezett eszköz alkalmazható. Az előkészítő eljárásnak a rendőri korrupció felderítésében kiemelt szerepe van. Azok a lehetőségek, amelyeket a 2018. július 1. napjáig hatályos Rtv. biztosított, a jelenleg hatályos törvényben már nem állnak fenn. A jogszabály arra ad lehetőséget, hogy a bizonyítékokat a felderítő szerv a Be. szabályai szerint gyüjtse be és használja fel. Az előkészítő eljárás is a gyanú megállapításáig folytatható, azt követően nyomozást kell kezdeményezni az eljárni illetékes nyomozó hatóságnál, és a további bizonyítékokat annak során kell beszerezni. A gyakorlatban könnyebbség a leplezett eszközök használata az előkészítő eljárást követő nyomozásban, mint az előző törvényi szabályozás idején. Az Rtv. korábbi, már hatálytalan szabályai szerint alkalmazott bírói engedélyhez kötött eszközökkel szerzett bizonyítékok feljelentés útján kerültek a nyomozásba. Büntetőeljárással párhuzamosan bírói engedélyhez kötött eszköz (például lehallgatás) alkalmazása nem történhetett párhuzamosan, hanem annak befejezésére kellett intézkedni. Amennyiben a nyomozásban erre szükség volt, akkor újbóli engedélyezést kellett kérni (titkos adatszerzés keretében). Az új szabályozás során az előkészítő eljárásban alkalmazott bírói engedélyhez kötött leplezett eszköz befejezésére nem kell intézkedni, elegendő csak a nyomozás kezdeményezésére. Az illetékes nyomozóhatóság, amennyiben a nyomozás elrendeléséröl, azon belül is a leplezett eszköz tovább folytatásáról határoz, úgy akkor be kell fejezni az előkészítő eljárást. Az eszköz folyamatosan tovább használható. Így az esetleges két engedélyezés közti adatvesztés kizárt. A hatályos Be. a titkos információgyüjtés és a titkos adatszerzés tekintetében jelentős újításokat hozott. Az új szabályozás megszüntette a titkos információgyüjtés és a titkos adatszerzés kettősségét, és ezzel a bizonyítékok elvesztésének lehetőségét jelentős mértékben csökkentette, egyben kimondja, hogy egy konkrét személlyel szemben bűnüldözési célból nem folyhat lényegében korlátlan ideig bírói engedélyhez kötött titkos információgyüjtés, ennek a határideje minden esetben maximalizált (Mátyás, 2017). A leplezett eszközök alkalmazása a korábbi szabályozáshoz hasonlóan szigorú feltételekhez kötött, mivel használatuk 
komoly beavatkozást jelent a magánszférába. Az új szabályozás leplezett eszközökről rendelkezik és ezeknek három csoportját különbözteti meg, melyek között vannak bírói vagy ügyészi engedélyhez kötött, illetve ilyen engedély nélkül végezhetök ${ }^{13}$. A bírói és ügyészi engedélyhez nem kötött leplezett eszközök között jelenik meg a rejtett megfigyelés, illetve az észleltek technikai eszközzel történő rögzítése ${ }^{14}$. A rejtett figyelés tárgya lehet a büncselekménynyel kapcsolatba hozható személy, lakás, egyéb helyiség, bekerített hely, nyilvános vagy a közönség részére nyitva álló hely, illetve jármü vagy tárgyi bizonyítási eszközt képező dolog megfigyelése. Természetesen nem értendők ide azok a helyiségek, melyek a bírói engedélyhez kötött titkos megfigyelés tárgyai lehetnek. Ki kell emelni egy újításként meghatározott eszközt, nevezetesen a megtévesztő információk közlését. Alkalmazásának lényege, hogy a büncselekmény megszakítása, a büncselekmény elkövetőjének azonosítása, illetve a bizonyítás érdekében az információ forrásának leplezésével a leplezett eszköz alkalmazásával érintett személlyel valótlan vagy megtévesztő információt közölnek. Az eszköz alkalmazását a törvényalkotó szigorú korlátok közé szorítja. A törvény indoklásában kiemelik, hogy a tilalmak egyik célja a tisztességes eljárás garanciális folytatásának biztosítása, másrészt pedig a bizonyítás torzításának megakadályozása. ${ }^{15} \mathrm{Ez}$ az eszköz nem alkalmazható terhelt, illetve tanú kihallgatása, bizonyítási cselekmény során, nem tartalmazhat törvénnyel össze nem egyeztethető ígéretet, nem valósíthat meg fenyegetést, felbujtást, és nem terelheti az érintett személyt súlyosabb büncselekmény elkövetése felé. Az eszköznek az alkalmazása - a korlátok figyelembevétele mellett - a korrupciós büncselekmények esetében is eredményt hozhat.

Az ügyészi engedélyhez kötött leplezett eszközök ${ }^{16}$ között megjelenik egy a korrupciós büncselekmények felderítése érdekében elöreláthatólag hatékonyan alkalmazható eszköz - a fizetési müveletek megfigyelése. Ennek keretében a pénzügyi szolgáltató az érintett személy vonatkozásában fizetési müveletekkel kapcsolatban ad információkat. Az eszköz keretében arra is lehetőség lesz, hogy egy adott fizetési müveletet felfüggesszenek. Egy másik leplezett eszköz a büntetőjogi felelősségre vonás elkerülésének kilátásba helyezése, melynek keretében lehetőség nyílik arra, hogy a büncselekmény elkövetőjével megállapodást kössenek. A megállapodás keretében rögzítik, hogy az elkövetővel szemben nem indul, vagy megszüntetésre kerül a büntetőeljárás, amennyiben az adott ügy, illetve más büntetöügy felderítésével, bizonyításával összefüggö

13 Be. 214. § (4).

14 Be. 215 . §.

15 Be. indoklása.

16 Be. 216-230. §. 
információkat és bizonyítékokat bocsát rendelkezésre. A korrupciós büncselekmények felderítése során előfordul, hogy olyan információk merülnek fel, melyek szervezett elkövetést valószínúsítenek, azonban ennek bizonyítása nehézségekbe, akadályokba ütközik. Ilyen esetekben hasznos lehet egy elkövetővel ilyen tartalmú megállapodás megkötése, melynek segítségével a szervezett elkövetés bizonyíthatóvá válik. Új eszközként nevesíti a törvény a hozzájárulással alkalmazott megfigyelést, melyre az ügyészség engedélye alapján, a sértett hozzájárulása mellett kerülhet sor. Alkalmazására uzsora-büncselekmény, kapcsolati erőszak, illetve zaklatás büncselekménye miatt, vagy olyan büncselekmény miatt van lehetőség, amely fenyegetéssel valósul meg. A leplezett eszközök alkalmazására feljogosított szerv a büncselekmény felderítése, illetve bizonyítása érdekében fedőokiratot készíthet, használhat, szervezetet hozhat létre és tarthat fenn, illetve fedőadatot jegyeztethet be. A titkos erök és eszközök speciális kombinációja az úgynevezett fedett nyomozó személye és tevékenysége, mely alapvetően krimináltaktikai eszköznek minősül, azonban egyben taktikai is, hiszen csapdát állít az elkövetöknek (Fenyvesi, 2014, 152.) Az új Be. a fedett nyomozók alkalmazásának feltételeit is meghatározza, valamint - az ellenőrizhetőség mellett - lehetőséget teremt a fedett nyomozók tanúkénti kihallgatására is. Ez a bizonyítást megkönnyítheti, de minden esetben csak úgy, hogy a fedett nyomozók biztonságának prioritást kell élveznie. A korrupciós büncselekmények felderítésére és bizonyítására is hatékony eszköz lehet a fedett nyomozó. A törvény adta lehetőségek közül elsősorban a rejtett figyelés végrehajtása és a büncselekménnyel összefüggő információk és bizonyítékok megszerzése esetén fontos az alkalmazásuk.

A bírói engedélyhez kötött leplezett eszközö ${ }^{17}$ között a törvény a következőket nevesíti: az információs rendszer titkos megfigyelése, a titkos kutatás, a hely titkos megfigyelése, a küldemény titkos megismerése és a lehallgatás. Az információs rendszer titkos megfigyelése során a leplezett eszközök alkalmazására az erre feljogosított szerv bírói engedéllyel információs rendszerben kezelt adatokat titokban megismerhet, az észlelteket technikai eszközzel rögzítheti. A titkos kutatás a nyilvános vagy a közönség részére nyitva álló hely kivételével lakás, egyéb helyiség, bekerített hely, továbbá a közösségi közlekedési eszköz kivételével jármü, illetve az érintett személy használatában lévő tárgy kutatható át titokban. A hely titkos megfigyelése során - a nyilvános vagy a közönség részére nyitva álló hely kivételével - a lakásban, egyéb helyiségben, bekerített helyen, illetve - a közösségi közlekedési eszköz kivételével - jármüvön történtek titokban technikai eszközzel megfigyelhetők és rögzíthetők. Másik

17 Be. 231-242. §. 
leplezett eszköz a küldemény titkos megismerése, melynek során a leplezett eszközök alkalmazására feljogosított szerv bírói engedéllyel postai küldeményt vagy egyéb zárt küldeményt titokban felbonthat, annak tartalmát megismerheti, ellenőrizheti és rögzítheti. A lehallgatás során elektronikus hírközlési szolgáltatás keretében elektronikus hírközlő hálózat vagy eszköz útján, illetve információs rendszeren folytatott kommunikáció tartalma titokban megismerhető és rögzíthető. A bírói engedélyhez kötött leplezett eszközök elsősorban az öt évig terjedő vagy ennél súlyosabb szabadságvesztéssel büntetendő szándékos büncselekmény esetén alkalmazhatók. Emellett azonban további lehetőségeket is felsorol a törvény. Így alkalmazhatók ezek az eszközök a három évig terjedő szabadságvesztéssel büntetendő, szándékosan elkövetett korrupciós büncselekmény (kivéve feljelentésének elmulasztása) esetén is. Az új Be. a bírói engedélyhez kötött leplezett eszközök alkalmazásának időtartamát is egyértelmüen meghatározza. Ennek megfelelően egy érintettel szemben legfeljebb kilencven napra engedélyezhető, amely alkalmanként legfeljebb kilencven nappal meghosszabbítható, de az érintett személlyel szemben bírói engedélyhez kötött leplezett eszközök alkalmazása összesen háromszázhatvan napig engedélyezhetö. A törvény szerint fö szabályként a leplezett eszköz által beszerzett adatok abban az ügyben és azzal a személlyel szemben használhatók, amely büntetöügyre és akire az engedély szólt, azonban bizonyos feltételekkel lehetőség van az alkalmazás kiterjesztésére is. ${ }^{18}$

\section{Összegzés}

A külföldi kriminalisztikai irodalom a 20. század második felében kezdett érdeklődni a titkos felderítés iránt, a hazai szakirodalom azonban csak az 1990-es évet követően tekintette tárgyának a titkosrendőri munkát (Bócz, 2004, 969.). Ezt követően azonban gyorsan egyre nagyobb szerepet kapott a büncselekmények felderítésében, bizonyításában. Megállapítható, hogy operatív tevékenységböl származó bizonyíték vagy tettenérés hiányában a korrupciós cselekmények nagyon nehezen bizonyíthatók, mert kevés a tanú és az okirati bizonyíték

18 Be. 241. § (1) „Az alkalmazás kiterjesztésének lehet helye, ha a leplezett eszközök alkalmazásának az engedélyben meghatározott befejezö idöpontjáig az érintett személlyel szemben a) az engedélyben nem szereplö más leplezett eszköz alkalmazása, illetve b) az engedélyben már megjelölt leplezett eszköz alkalmazásának folytatása információs rendszer titkos megfigyelése esetén más információs rendszer; titkos kutatás esetén más helyiség, jármü vagy tárgy; hely titkos megfigyelése esetén más helyiség vagy jármü; küldemény titkos megismerése esetén más hely, illetve más feladó vagy címzett; lehallgatás esetén más elektronikus hírközlési szolgáltatás vagy eszköz, illetve más információs rendszer vonatkozásában szükséges." 
(Török, 2010, 5-16.). Ezzel összecseng, hogy a rendőrök szerint a korrupciós büncselekmények vonatkozásában az egyik leghatékonyabb felderítési technika a titkos információgyüjtés (Inzelt, Kerezsi \& Lévay, 2014, 92.). Tekintettel arra, hogy - speciális jellemzői miatt - a rendőri korrupció tettenérése is komoly kihívás elé állítja a hatóságokat, és ez csak kivételes esetben valósul meg, a leplezett eszközök alkalmazása elengedhetetlen a rendőri korrupciós cselekmények elleni küzdelemben. A titkos felderítések jogszabályi környezetét átgondoltan, pontosan és gyakorlatorientált módon kell kidolgozni, hiszen az annak alapján végzett bünüldözési tevékenység és a jogalkalmazás alapjaiban befolyásolja az ilyen büncselekmények felderítésének, nyomozásának, ezzel együtt a büntetésének sikerességét, vagyis közvetetten a bünelkövetők speciális és generális elrettentését a bünözéstől (Gábri, 2015, 55.). A megfelelő szabályozás alapot ad a leplezett eszközök hatékony és eredményes alkalmazásához, a rendőri korrupciós büncselekmények elkövetőinek felelősségre vonásához. Finszter Géza megállapítja, hogy „a titkos felderités szükséges és arányos bevetésével a korrupció legsúlyosabb eseteiben, beosztásra és pártállásra tekintet nélkül, mindenkivel szemben érvényesithetö lehet az állam büntetöigénye, ami valódi visszatartó eröt képviselhet" (Finszter, 2011, 97.). Az új Be. általi szabályrendszer sok esetben hasznos, de - a gyakorlati tapasztalatok alapján - nem fedi le a felderítés teljes igényrendszerét, így szükséges lenne módosítása. Erre példa, hogy a Be. alapján az NVSZ csak a jogszabályban nevesített szervektől kérhet adatot. A valóságban sokkal több adatkezelő szerv van, amelyeket az eredményes felderítés és bizonyítás érdekében szükséges megkeresni. A jelenlegi korlátozás miatt nem kérhető adatszolgáltatás - többek között - a Nemzetbiztonsági Szakszolgálattól, az önkormányzatoktól (például közterületi kamerafelvételek érdekében), a Terrorelhárítási Információs és Bünügyi Elemző Központtól (TIBEK), a Nemzeti Adó- és Vámhivatal Központi Irányítás Pénzmosás és Terrorizmusfinanszírozás Elleni Irodától (NAV PEI), a kormányhivataloktól, az ügyészségektől, a bíróságoktól, a rendőrség, illetve más állami szerveknek bizonyos nyilvántartásaiból (például személyügyi nyilvántartásából, objektumba be- és kilépő személyek nyilvántartásából, gazdasági beszerzésekről). További nehézséget jelent, hogy az együttmüködők védelme továbbra sem megoldott, kihallgatásuk jelenleg az ügyészség döntésén múlik. Az új Be. fontos és rendkívül üdvözlendő újítása, hogy több rendelkezéssel igyekszik szavatolni, a fedett nyomozók biztonságát, lelepleződésük megakadályozását (Mészáros, 2019, 122.). Annak érdekében, hogy könnyebben lehessen együttmüködőt bevonni és ezzel a korrupciós büncselekményeket felderíteni, bizonyítani, a fedett nyomozóhoz hasonló, azonban annál szigorúbb védelem lenne indokolt számukra. Az együttmüködő rendszerint nagyobb kockázatot vállal, mint a fedett nyomozó. 
A fedett nyomozó általában egy fiktív személyazonossággal rendelkező rendőr, akinek a valódi személyazonosságát feladatellátása során a vele kapcsolatba kerülő személyek nem ismerik meg. Ezzel szemben az együttmüködő a meglévő kapcsolatrendszerét kihasználva, rendszerint saját környezetéből szerzi meg azokat az információkat, melyek elősegítik a bünüldözési tevékenységet. Az együttmüködőt a kapcsolattartó szerv rendszerint a továbbiakban is alkalmazni kívánja, ezért személyének védelme különösen indokolt. Az eljáró szerv akkor tudja az együttmüködőket alkalmazni, ha az előkészítő eljárás során törvényi garanciát tud vállalni arra, hogy nem kerül kihallgatásra a büntetőeljárásban. A felvetődött problémák megoldása érdekében az NVSZ a jogszabály módosítására tett javaslatot. Az operatív tevékenység megfelelö, részletes szabályozása elengedhetetlen, de közel sem elégséges a rendőri korrupció elleni hatékony és eredményes fellépéshez. A leplezett eszközök használata ugyanis a más nyomozási cselekményekhez képest nagyobb odafigyelést, különös szakértelmet igényel az azt alkalmazó gyakorlati szakemberektől. A rendőri korrupciós büncselekmények vonatkozásában a leplezett eszközök közül a gyakorlati tapasztalatok alapján - a kép- és hangrögzítő eszközök alkalmazása, a fedett nyomozó, a rejtett megfigyelés, a titkos kutatás alkalmazhatók a leghatékonyabban. A lehallgatás ezeknél a büncselekményeknél az utóbbi időben ritkán hoz releváns adatot, így a felderítés szakaszában a humán pozícióknak újra kiemelt fontossága lett. A titkos technikák felértékelődése a jövőben is folytatódni fog, sőt számítani lehet további alkalmazási szélesedésre, új metódusok bevezetésére, alkalmazására is. Ehhez alapot ad a digitális adatok felkutatása, hiszen a digitális technikai tudás és eszközbázis folyamatosan fejlődik (Fenyvesi, 2014, 242.). Mind a korrupciós, mind más büncselekmények elkövetőire igaz, hogy a technika fejlődését kihasználják, az abban rejlő lehetőségeket rendszerint alkalmazzák. A korunkra jellemző robbanásszerü információtechnológiai fejlődés a technikai fejlesztések terén komoly kihívás elé állítja a titkos információgyüjtést folytató, a leplezett eszközöket alkalmazó szervezeteket (Boda, 2015. 29.). Ez a fejlődés olyan rohamos és szerteágazó (gondoljunk csak bele hány kommunikációt elősegítő csevegő alkalmazás van), hogy szinte követhetetlen. A hatóságok rendelkezésére álló módszerek egyre távolabb kerülnek a napról napra ismertté vált, sokak számára elérhető alkalmazásoktól. Kiemelt fontosságú lenne, hogy ezen a területen komoly előrelépés történjen, ami jelentős kiadást jelentene ugyan, de ha a hatóság nem akar behozhatatlanul lemaradni, akkor lépéseket kell tenni. A gyakorlatban a felderítő szervek addig nem tudnak mit tenni, mint a már említett humán hírszerzési pozíciókat szélesítik annak ellenére, hogy a Be. adta lehetőségek éppen a hosszútávú, konspirált kapcsolattartásnak nem kedveznek. 


\section{Felhasznált irodalom}

Balláné Füszter E. (2014): Kriminalisztikai ismeretek. Nemzeti Közszolgálati Egyetem

Boda J. (2015): A felderítés, hírszerzés, titkos információgyüjtés elvei és gyakorlata. Belügyi Szemle, 63(9), 29.

Bócz E. (szerk.) (2004): Kriminalisztika 2. Duna Palota és Kiadó

Budaházi Á. (2013): A müszeres vallomásellenőrzés, különös tekintettel a poligráfos vizsgálatra. Doktori értekezés. Pécsi Tudományegyetem, Állam- és Jogtudományi Kar

Budaházi Á. (2018): A műszeres vallomás-ellenőrzés hazai gyakorlata egy empirikus kutatás tükrében. Magyar Rendészet, 18(2), 27-42.

Czobor P., Kakuszi B., Fantoly Zs., Bitter I. \& Budaházi Á. (2018): A büntetőeljárásban alkalmazható agyi ujjnyomat (brain fingerprinting) vallomás-ellenőrzési módszer, és annak neurobiológiai alapja, a P300 agyhullám. Magyar Rendészet, 18(2), 65.

Fenyvesi Cs. (2014): A kriminalisztika tendenciái. Dialóg Campus Kiadó

Finszter G. (2000): A titkos információgyűjtés szabályozása a hatályos jogban. Kriminológiai Tanulmányok, 37, 110.

Finszter G. (2011): A korrupció nyomozása. Belügyi Szemle, 60(11), 97.

Gábri A. (2015): Titkos adatszerzés a hatékony bünüldözés szolgálatában. Büntetőjogi Szemle, 63(3), 55.

Hautzinger Z. (2004): Az igazságügyi őszinteségvizsgálat. In Korinek L., Kőhalmi L. \& Herke Cs. (szerk.): Emlékkönyv IRK Albert egyetemi tanár születésének 120. évfordulójára. Pécsi Tudományegyetem, Állam- és Jogtudományi Kar, 43-51.

Hautzinger Z. (2019): Gondolatok a kriminalisztika elméleti rendszeréröl. JURA, 25(1), 84.

Inzelt É., Kerezsi K. \& Lévay M. (2014): Korrupciós büncselekmények a büntető igazságszolgáltatás tükrében. ELTE Állam- és Jogtudományi Kar

Kaiser T. (szerk.) (2017): Jó állam jelentés. Dialóg Campus Kiadó

Mátyás F. (2017): Átalakul a titkos információgyüjtés rendszere. Jogászvilág, 3(2), 22.

Mészáros B. (2018): A bünügyi hírszerzés új rendszere hazánkban. In Gaál Gy. \& Hautzinger Z. (szerk.): A XXI. század biztonsági kihívásai. Magyar Hadtudományi Társaság Határőr Szakosztály Pécsi Szakcsoport - Magyar Rendészettudományi Társaság

Mészáros B. (2019): Fedett nyomozó alkalmazása a bünüldözésben. Dialóg Campus

Nyitrai E. (2014): A titkos információgyüjtés és a titkos adatszerzés alkalmazása során felmerülő kérdések. Büntetőjogi Szemle, 62(3), 32.

Rudas Gy. \& Hoffman L. (szerk.) (1973): Kriminalisztika Különös Rész II. (Metodika). BM Tanulmányi és Propaganda Csoportfőnökség

Török Zs. (2010): Hivatali és korrupciós büncselekmények bírói gyakorlatának aktuális kérdései 2. rész. Ügyészek Lapja, 17(3-4), 5-16. 


\section{A cikkben találhat online hivatkozások}

URL1: Papp-Nagy Zs.: Leplezett eszközök-Alkalmazás az új Be. alapján. https://www.jogiforum.hu/hirek/41170

\section{Felhasznált jogszabályok}

2017. évi XC. törvény a büntetőeljárásról

A Rendőrségről szóló 1994. évi XXXIV. törvény

A rendőrség belső bűnmegelőzési és bűnfelderítési feladatokat ellátó szerve kijelöléséről, valamint feladatai ellátásának, a kifogástalan életvitel ellenőrzés és a megbízhatósági vizsgálat részletes szabályainak megállapításáról szóló 293/2010. (XII. 22.) kormányrendelet

20/2013. (V. 17.) ORFK utasítás a rendőri korrupciós cselekmények megelőzésével és visszaszorításával kapcsolatos feladatokról 